\title{
Social Media Reporting and Firm Value
}

\author{
Abdalmuttaleb Musleh Al-Sartawi [0000-0001-9755-5106] , and Allam Hamdan \\ Ahlia University, Manama, Bahrain \\ amasartawi@hotmail.com, ahamdan@ahlia.edu.bh
}

\begin{abstract}
Technologies are changing how stakeholders, and investors access and capture data. Social Media has had a dramatic impact on how firms communicate with investors and stakeholders about their financial and sustainability reporting, giving them an edge over their competitors. The aim of this paper is to investigate the relationship between social media reporting and firm value of the GCC listed firms. To answer to research questions, the researchers collected cross-sectional data from a sample of 241 firms listed in the financial stock markets of the GCC for the year 2017. Additionally, an Index was used to calculate the total level of social media disclosure. The findings show that the $84 \%$ of firms in the GCC countries use social media, while $70 \%$ of these firms use SM for reporting. The results indicate that enhanced reporting levels through various social media channels significantly influence value of firms. These results have implications for GCC listed firms as it is important to examine how they can utilize social media to enhance their reporting process.
\end{abstract}

Keywords: Social Media Reporting, Tobin's Q, Sustainability Reporting, GCC Countries. 


\section{Introduction}

Technologies are changing how stakeholders, and mainly, investors access and capture a firm's data. Firms are recognizing the importance of the data they own and that the way it is used can provide them with an edge over their competitors. Social Media (SM), in particular, has had a dramatic impact on how firms engage in dialogue with investors as it allows in producing immediate and large quantities of data in many forms including videos, images, and audios. SM is based on the technological and ideological foundations of Web 2.0 which allows the creation and exchange of user generated content [18], unlike the Web 1.0 which is a set of static websites that do not provide interactive content.

While many firms are still using paper-based means and static websites (Web 1.0) to disclose information to stakeholder, others are jumping on the trending social media bandwagon (Web 2.0). Offering a variation in the way information reach investors will ensure that firms are being heard. In April 2013, the Securities and Exchange Commission issued a report stating that firms can use SM tools such as Facebook and Twitter to announce key information in compliance with Regulation Fair Disclosure [29]. Based on the Canadian Investor Relations Institute [11], the role of social media in financial and sustainability reporting is increasing as firms that may have primarily used social media for marketing purposes are now expanding their scope to include investors. Similarly, [22] claim that the use of internet-based communications by firms, mainly social media, is growing rapidly. Whereas, firms ignoring SM will be disadvantaged within the investment community [3].

These developments have considerable implications for accounting practices due to the demand of stakeholders for instant access to wide-ranging information related to a firm's governance, performance, finances, operations, and practices [22]. Therefore, amidst these significant developments the incentive for this paper is imminent, as it is important to examine how social media can be utilized to enhance the reporting process. [1] believes that the disclosure process should encompass the formal as well as the informal communications and interactions with the various stakeholders, and not simply sharing a single and static annual report on the firm's website. [7] found that institutional investors analyze firms and make recommendations based on information they find on social media searches.

Consequently, by improving the quality of communication and reducing information costs, firms may reduce the cost of their capital [5]. According to [23], that firms which aim to increase their value might choose a disclosure position which will allow their higher position to be disclosed, as opposed to firms with lower performance, which will choose a disclosure position to legitimize their performance. It enhances transparency by disclosing symmetrical information and reducing the costs associated with the agency problem, thus adhering to the principles of corporate governance [6] This paper, henceforth, defines social media reporting as the public reporting of financial, operating and sustainability information by firms through social media.

Despite the importance of such a research paper, there are negligible studies that provide evidence on the relationship between social media reporting and firm value, certainly none related to the GCC countries. Therefore, this explanatory paper attempts 
to develop a better understanding of the effects of social media reporting on the firms listed in the GCC stock markets, whereby the main purpose is to determine whether information transparency has an impact on firm value, with a particular emphasis on Tobin's Q. This paper extends on previous research which focused on website-based disclosure through Web 1.0 and delves into social media reporting through Web 2.0.

From a theoretical perspective, this paper contributes to the literature by addressing a new and important topic within the context of the study. Moreover, from a practical perspective, the paper offers implications for firms to utilize social media to improve transparency and enhance their reporting process. This paper offers another contribution by proposing a Social Media Reporting Index (SMRI), based on the framework of prior studies relevant to web-based disclosure such as [4, 23]. As such, this paper's research questions are: What is the level of SM reporting in the GCC countries? And, what is the relationship between SM reporting and firm value.

The GCC is selected as a context to study due to its unique environment in relation to the advancements in technology. They have recently introduced their own corporate governance codes to enhance the social and regulatory environments, hence attracting more investors by encouraging voluntary disclosure. According to its geographical location, the GCC is at the heart of the Middle East, providing quick and efficient access to every market in the region. It has, therefore, become an intended destination for many foreign investors. These investors ask for financial information and carry on with certain decisions whether to continue with a certain company or not, and this is provided through social media.

The GCC countries such as Saudi Arabia and UAE are among the world's leading nations in terms of social-media growth and use, driven by smartphone ownership, high levels of internet penetration and a large, digitally savvy youth population [17]. Another study, [8], states that in the GCC, consumers and investors believe that social media encourages consumer-centric and transparent approaches, and is an instant platform to get news and information. Moreover, they believe that it offers for a cheap means of communication despite that SM poses a threat to traditional media by taking a piece of their market shares. This willingness to accept SM in business provides an interesting perspective for investigating the level of SM usage by firms and its relation to firm value.

\section{$2 \quad$ Literature Review}

Social media has boomed as a platform that people use to create content, share, network, and interact at a phenomenal rate. SM such as Facebook, Twitter, YouTube refer to technology-facilitated dialogue conducted through platforms including blogs, wikis, content sharing, social networking, and social bookmarking. According to [27], many firms are using social media as another outlet for their external and internal corporate communication about sustainability.

The value of SM is engagement. Corporate social media facilitates firm-directed, one-to-many communications that bypass traditional media and allow a firm to broadcast its intended message to a large network of stakeholders which is instantly made 
visible to all [20]. [24] found out that Chief Financial Officers believe that their decisions which are related to disclosures have high implications. Therefore,[19], claim that the recent changes in technology, capital markets and the media affect and are affected by firms' disclosure policies, whereby regulators as well as companies are starting to embrace social media as a viable disclosure channel for important information such as sustainable development activities. [12] claim that most large global corporations report at least some sustainability performance data annually through social media. Social media can, hence, be leveraged as to convey the firm policy and assist in their mission to support the United Nation's sustainable development goals.

[22] argue that social media provide investors, who have no direct channel of communication with the management, a voice to question decisions that give management incentives to take action. The use of SM for disclosure enables interaction between the stakeholders, and not merely between the stakeholders and the firms. This adds a new dimension to corporate reporting, as what had been previously found regarding investors' reactions to corporate reporting cannot be applied to their reactions in today's dynamic environment [19]. [27] argue that the level of commitment to sustainability reported through social media may yield important insights regarding the firm's business strategy. For example, a firm's mission statement may directly reference sustainability-related values. [10] argues that as investors and other stakeholders depend on SM for firm news and investment advice, firms that fail to take part in the conversation will be singled out for remaining silent. Hence, the previous researches which focused more on Web 1.0 need to be extended methodically to include more relevant issues such as SM disclosure on sustainable development activities.

SM channels are more widely available to investors and allow for interaction between users via postings and comments [14] Firms usually choose SM as a part of their overall strategy to for online disclosure which aims to create a positive reputation and increase their value [25]. Firms also use SM as part of their strategy to reduce information asymmetry, increase transparency, and reduce agency-related costs [8]. Agency losses normally arise when there is a conflict between the desires or goals of the principal (shareholder) and the agent (manager), and it is difficult or expensive for the shareholder to determine what the manager is actually doing [14]. The agency theory hence attempts to reduce agency losses by specifying mechanisms such as tying their compensation with shareholder returns.

Increased transparency is often achieved through voluntary disclosure. Therefore, to let the shareholders know what they are doing, managers need to reach stakeholders through different medium. [13] claim that managers know that shareholders aim to control their behavior through monitoring activities. Consequently, managers have incentives to disclose more information to show shareholders that they are acting optimally. Managers might opt to disclose information through SM due to the wide-range of benefits it offers such as low cost, timely information, and a wide-reach two-way communication platform. More transparency and better disclosure are associated with equality among investors, less insider trading and lowers uncertainty in investment decisions [25] For example, when the CEO of Netflix posted on Facebook that Netflix's monthly online viewing is more than one billion hours, the stock price increased in one day by 
$6.2 \%$ [30]. This indicates that SM disclosure has a direct influence on stock price, and by extension firm value.

[8] argued that social media channels, mainly Twitter, reduces information asymmetry, as other researchers [9] found that by increasing the dissemination of the same information leads to a reduction in information asymmetry. According to [4] enhancing voluntary disclosure can motivate top managers to improve firm value because of increased pressure from the intensive monitoring of outside shareholders. As market values depend on investor confidence presumably through increased and transparent disclosure, market evaluation could be measured using Tobin's Q. Tobin's Q is computed as the ratio of the market value of the firm's outstanding debt and equity divided by the book value of assets [16]. A prior study by [21] used Tobin's Q to examine the relationship between corporate disclosure and performance, and they reported a positive and significant association between the two variables.

Several researches have attempted to explore social media reporting; however, as this is a new trend, these studies mainly focus on the literature, SM adoption, and the determinants of social media reporting $[10,19,25,30]$. From these studies, we can assume that the topic of SM as a disclosure platform is gaining momentum, and this paper offers a contribution by taking part in the conversation. However, what differentiated this paper from previous studies is that this study empirically investigates the relationship between SM disclosure and firm value. This paper, therefore, hypothesizes that: There is a relationship between social media reporting and firm value measured through Tobin's Q.

\section{$3 \quad$ Research Methodology}

The empirical study of the current research depended on a sample which consisted of all the listed firms in the GCC stock exchange markets for the year 2017. The required data were gathered from 241 companies out of 289 companies listed under financial sector. The financial sector was chosen for the study due to the large size of the banking industry in the GCC countries. The GCC countries are gradually undergoing a shift in their economies, from oil-dependent economies to more diversified economies, focusing mainly on the financial sector as the largest non-oil contributor to their GDPs. Table (1) shows the sample distribution according to country and industry type (Banks, Insurance and Investment).

Table 1: Sample distribution according to country and industry

\begin{tabular}{cccccccc}
\hline Industry & KSA & UAE & QAT & BAH & KUW & \multicolumn{2}{c}{ Per Industry } \\
\hline Banks & 11 & 33 & 8 & 7 & 8 & 67 & $28 \%$ \\
Insurance & 32 & 31 & 4 & 5 & 7 & 79 & $32 \%$ \\
Investment & 7 & 19 & 4 & 10 & 55 & 95 & $40 \%$ \\
\hline Per Country & $\mathbf{5 0}$ & $\mathbf{8 3}$ & $\mathbf{1 6}$ & $\mathbf{2 2}$ & $\mathbf{7 0}$ & $\mathbf{2 4 1}$ & $\mathbf{1 0 0 \%}$ \\
\hline
\end{tabular}


Consequently, the study applies a two-stage process to measure (1) the level of usage of Social Media (SM) in UAE firms as well as (2) the level of Social Media Reporting of those firms. Therefore, some firms might use social media, but not for reporting financial and sustainability information. These were excluded from the study.

The first stage involved measuring the social media usage by GCC listed firms. In order to measure the percentage of usage of SM, the study use the binary data method, i.e., if a firm uses any type of social media platform (Facebook, Twitter, Instagram, Snapchat, YouTube, LinkedIn, others) it received a score of 1 . However, if the firm did not use any form of SM platform it received a score of 0. Similarly, the second stage involved measuring the level of SMR for firms using SM in stage 1. So, if a firm used SM to report financial/sustainability information it received a score of 1 , and if a firm did not use its SM to report financial/sustainability information it received a score of 0 . Accordingly, the Index for each firm was calculated by dividing the total earned scores of the firm by the total maximum possible scours appropriate for the firm. To secure the data on the social media applications and channels from any updates or changes during the time of the study, all information, hyperlinks and images were downloaded and saved as HTML files beforehand. Below formula shows the way of calculating the SMR index.

$$
S M R=\sum_{i=1} \frac{d i}{n}
$$

Where:

di: disclosed item equals One if the bank meets the checklist item and zero otherwise. $\mathrm{n}$ : equals maximum score each bank can obtain.

To test the hypothesis, the following regression model was developed using SMR as an independent variable, and Tobin's $Q$ as the criterion variable. Additionally, the study used firm age, firm size and financial leverage as control variables.

\section{Model}

$$
T Q=\beta_{0}+\beta_{1} S M D_{i}+\beta_{2} L F S Z_{i}+\beta_{3} L V G_{i}+\beta_{4} A G E_{i}+\varepsilon_{i}
$$

\begin{tabular}{|c|c|c|}
\hline Code & Variable Name & Operationalization \\
\hline \multicolumn{3}{|c|}{ Dependent variable } \\
\hline TQ & Market value add & Total Market Value / Total Assets Value \\
\hline \multicolumn{3}{|c|}{ Independent Variables -: } \\
\hline SMR & Social Media Reporting \% & Total scored items by the company/Total maximum scores \\
\hline \multicolumn{3}{|c|}{ Control Variables: } \\
\hline LFSZ & Firm size & Natural logarithm of Total Assets \\
\hline LVG & Leverage & Total liabilities/ Total Assets \\
\hline AGE & Firm Age & $\begin{array}{l}\text { The difference between the establishing date of the firm and the report } \\
\text { date }\end{array}$ \\
\hline
\end{tabular}

Table 2: Study Variables 


\section{Data Analysis}

\subsection{Descriptive Statistics}

Table 3 reports the descriptive analysis of the independent, dependent and control variables. The overall mean of Tobin's Q was 1.07 by GCC firms with a minimum of 0.68 and maximum of 2.55 indicating that the majority of the firms are overvalued as their stocks are higher than the replacement costs of their assets. This proxy exposes the potential of added value of the firm as viewed by the market as a reflection of its performance. Therefore, if Tobin's Q is greater than 1, it indicates that the firm has a market value exceeding the price of the replacement of its assets. With regards social media usage, show the show that the overall level of firms in the GCC countries that use social media was $84 \%$, which is considered as a moderate level of usage of SM. Additionally, the results show that of the $84 \%$ of firms that use SM, $70 \%$ use SM for financial and sustainability disclosure, which again indicates a moderate level of disclosure through SM.

In addition to the dependent and independent variables, the descriptive statistics for control variables show that the mean of firm size was $84,43,579$, with a minimum of $4,06,832$ and a maximum $3,412,461.54$, implying large firms. As according to table (5) firm size was not normally distributed due to the significance of the KolmogorovSmirnov test being less than 5\%, so natural logarithm was used in the regression analysis to reduce skewness and bring the distribution of the variables nearer to normality. Moreover, the mean leverage of the firms was approximately $42 \%$, with a minimum of $4 \%$ and a maximum of $87 \%$, indicating that most GCC firms have a medium level of debts. Finally, firm age ranges from 2 to 64 with a mean of 33.45 .

Table 3: Descriptive Statistics for continues variables

\begin{tabular}{lccccc}
\hline Variables & N & Minimum & Maximum & Mean & Std. Deviation \\
\hline TQ & 241 & 0.68 & 2.55 & 1.07 & 0.09025 \\
Firm Size & 241 & 406832.3 & 3412461.54 & 8443579 & 220268.40264 \\
LVG & 241 & 0.04 & 0.87 & 0.4254 & 0.26508 \\
AGE & 241 & 2 & 64 & 33.45 & 13.004 \\
\hline \multicolumn{5}{c}{ Achieved } \\
Variables & Descriptive Statistics for non-continuous variables \\
SMR & Number & Percentage & \multicolumn{3}{c}{ Not achieved } \\
SML & 89 & $70 \%$ & \multicolumn{3}{c}{ Number } \\
\hline
\end{tabular}

\subsection{Testing Regression Assumptions}


A Variance Inflation Factor (VIF) test was used to check the data for multicollinearity. The VIF scores for each variable, both independent and dependent, are reported in Table (4). The results indicate that since no VIF score exceeded 10 for any variable in the model, while no Tolerance score was below 0.2. So, it was concluded that there is no threat of multicollinearity.

Table 4: Collinearity Statistics Test

\begin{tabular}{ccc}
\hline Model & Tolerance & VIF \\
\hline SMR & .717 & 1.107 \\
Firm Size & .805 & 1.206 \\
LVG & .733 & 1.080 \\
AGE & .826 & 1.098 \\
\hline
\end{tabular}

In addition to test for homoscedasticity and linearity, an analysis of residuals, plots of the residuals against predicted values as well as the Q-Q and scatter plots were conducted. Therefore, wherever there was a problem of heteroskedasticity the data were transformed. Autocorrelation test was not conducted in this research as the data used are cross-sectional.

Table 5: Kolmogorov- Smirnov Test

\begin{tabular}{lll}
\hline & Statistics & Sig. \\
\hline Tobin's Q & 2.137 & 0.165 \\
SMR & 2.009 & 0.381 \\
Firm Size & 2.044 & 0.003 \\
LVG & 2.095 & 0.540 \\
AGE & 2.113 & 0.347 \\
\hline
\end{tabular}

Finally, the Kolmogorov-Smirnov test used to assess the normality of the collected data for the variables. As table 5 illustrates, a significance level of more than $5 \%$ for all the variables except for firm size indicates that the data are normally distributed. With regards to firm size however, the variable was adjusted using natural logarithm.

\subsection{Testing the Hypotheses}

Table 6 reports the findings of the regression analysis. The findings indicate that the model was reflecting the relationship between the variables in a statistically appropriate way. According to the table, the model has an adjusted R2 of 0.303 which shows that the model explains approximately $30 \%$ of the variation in the Tobin's Q amongst the GCC listed firms. Additionally, the probability of the F-statistic with a significance 0.026 means that the independent variables are significant in interpreting the dependent variable, Tobin's $Q$.

Table 6: Regression analysis

\begin{tabular}{lccc}
\hline Variables & Beta & T. test & Sig. \\
\hline SMR & .432 & 8.678 & $.008^{* * *}$
\end{tabular}




\begin{tabular}{lccc} 
Firm Size & .277 & 2.683 & .187 \\
LVG & -.056 & -.938 & .207 \\
AGE & -.184 & -1.546 & $.000 * * *$ \\
\hline $\mathbf{R}^{2}$ & \multicolumn{3}{c}{16.283} \\
$\mathbf{F}$ & \multicolumn{3}{c}{.026} \\
Prob. (F) & *Prob. <10\%, **Prob. <5\%, ***Prob. <1\%
\end{tabular}

The main hypothesis of the study states that there is a relationship between the level of social media reporting and firm value (Tobin's Q) by firms listed in the GCC stock exchange markets. The result indicates that there is a significant and positive relationship between the level of SMR and firm value, that is, the higher the level of disclosure, the higher the Tobin's Q. This is in line with the studies conducted by [5] who suggest that the level and quality of disclosure affect firm value. Another study conducted in the MENA region [2] found a positive relationship between disclosure and firm value. This indicates that investors and other stakeholders react positively to information about the sustainable development activities that firms undertake towards achieving their sustainable goals. However, an earlier study conducted by [15] in the Middle East found no relationship between disclosure and firm value, which could be due to the lack of control for the endogeneity of the disclosure variable in relation to Tobin's Q. One reason for this could be the potential of SM as a two-way communication platform that allows timely dissemination of information to investors, shareholders and other stakeholders. This way all parties involved transmit information instantaneously, which helps them in making well-informed decisions. Furthermore, firms are able to receive instant feedback from their stakeholders which helps managers in making improvements, accordingly, thus satisfying all parties involved and reducing costs related to agency.

With regards to the control variables, the study found a significant and positive relationship between firm value and age. Based on [28] who also found a positive association between age and firm value, investors have a higher level of confidence and trust in older firms due to their experience and maturity. On the other hand, this contradicts the study by [26] who claim that firm value declines as investors learn about the firm's profitability or as their uncertainty resolves over time. Finally, the results show no relationship between firm value and the other control variables, firm size and leverage.

\section{Conclusion and Recommendations}

The paper aimed to address several research questions: (1) the level of social media usage by GCC listed firms, (2) the level of social media reporting (SMR) by GCC listed firms and (3) the relationship between social media reporting and firm value of the GCC listed firms. To answer to research questions, the researchers collected data from a sample of 241 firms listed in the financial stock markets of the GCC for the year 2017. Due to the nature of the data collected which is cross-sectional only one year was chosen to gauge the data at a specific point in time. 
The findings show that the $84 \%$ of firms in the GCC countries use social media, while $70 \%$ of these firms use SM for financial and sustainability disclosure. The results also confirm the hypothesis that enhanced disclosure levels through various social media channels of GCC listed firms significantly influence the firm value of these firms. This indicates that investors react positively to firms which engage in sustainable development activities, and communicate this clearly to stakeholders. In the days of Web 1.0, firms used to simply publish their annual reports as PDFs online, thus failing to capture the opportunities of two-way communication. However, when firms follow a similar approach to their utilization of social media, it is considered as a wasted potential. This paper recommends that firms give their information disclosure a face, whereby they listen to stakeholders more than they talk. Firms can, therefore, get insights, new ideas, complaints as well as warning signs to change.

From a theoretical standpoint, these results have implications for both social media reporting literatures and value relevance literatures in the GCC countries. From a practical perspective, this study provides contributions to GCC's government, policymakers and regulators with regards to a trending issue such as the modern disclosure tools that could be used by firms to increase transparency and reduce the agency problem. Policy makers and regulators in the GCC can make use of information from this research in setting new policies on social media disclosure in line with the Securities and Exchange Commission which recognized the potential of SM as a platform for reporting.

This paper suggests having a study that further investigates the relationship between social media reporting and other types of performance such as financial and sustainability performance. Future studies could also investigate the level of corporate social responsibility disclosure or intellectual capital of firms on social media.

\section{References}

1. Adams, C. A. (2015). The international integrated reporting council: a call to action. Critical Perspectives on Accounting, 27, 23-28.

2. Al-Akra, M., \& Ali, M. J. (2012). The value relevance of corporate voluntary disclosure in the Middle East: The case of Jordan. Journal of Accounting and Public Policy, 31(5), 533-549.

3. Alexander, R. M., \& Gentry, J. K. (2014). Using social media to report financial results. Business Horizons, 57(2), 161-167.

4. Al-Sartawi, A. (2018a), Corporate Governance and Intellectual Capital: Evidence from Gulf Cooperation Council Countries, Academy of Accounting and Financial Studies Journal, Vol. 22, No. 1, 1-12.

5. Al-Sartawi, A. (2018b), Does Institutional Ownership Affect the Level of Online Financial Disclosure? Academy of Accounting and Financial Studies Journal, 22 (2), 1-10.

6. Al-Sartawi, A., and Sanad, Z., (2019) Institutional ownership and corporate governance: evidence from Bahrain, Afro-Asian Journal of Finance and Accounting, 9 (1),101 - 115.

7. Arab Social Media Report (2015). Available at [http://sites.wpp.com/govtpractice// /media/wppgov/files/arabsocialmediareport-2015.pdf.]

8. Blankespoor, E., Miller, G. S., \& White, H. D. (2014). The role of dissemination in market liquidity: Evidence from firms' use of Twitter', The Accounfing Review 89 (1), 79-112.

9. Bushee, B. J., Core, J. E., Guay, W., \& Hamm, S. J. (2010). The role of the business press as an information intermediary. Journal of Accounting Research, 48(1), 1-19. 
10. Cade, N. L. (2018). Corporate social media: How two-way disclosure channels influence investors. Accounting, Organizations and Society.

11. CIRI (2012). The role of social media in performance reporting: A discussion brief. The Canadian Institute of Chartered Accountants, Available at [https://www.cpacanada.ca/-/me$\mathrm{dia} /$ site/business-and-accounting-resources/docs/role-of-social-media-in-performance-reporting-a-discussion-brief-

2012.pdf?la=en\&hash=394D1825712E8FC2F1ED7DBC68747B12F1E2225C]

12. Clark, A. (2008, February 5). Selling sustainability. Retrieved June 2, 2019, from http://www.climatebiz.com/blog/2008/02/06/selling-sustainability

13. Dolinšek, T., Tominc, P., \& Lutar Skerbinjek, A. (2014). The determinants of internet financial reporting in Slovenia. Online Information Review, 38(7), 842-860.

14. Eisenhardt, K. M. (1989). Agency theory: An assessment and review. Academy of management review, 14(1), 57-74

15. Hassan, O. A., Romilly, P., Giorgioni, G., \& Power, D. (2009). The value relevance of disclosure: Evidence from the emerging capital market of Egypt. The International Journal of Accounting, 44(1), 79-102.

16. Himmelberg, C. P., Hubbard, R. G., \& Palia, D. (1999). Understanding the determinants of managerial ownership and the link between ownership and performance. Journal of financial economics, 53(3), 353-384.

17. Internet World Stats (2018). CIA World Factbook: Middle East Media.org. Available at [https://www.zdnet.com/article/whats-driving-middle-easts-rush-to-social-media/]

18. Kaplan, A. M., \& Haenlein, M. (2010). Users of the world, unite! The challenges and opportunities of Social Media. Business horizons, 53(1), 59-68.

19. Lardo, A., Dumay, J., Trequattrini, R., \& Russo, G. (2017). Social media networks as drivers for intellectual capital disclosure: Evidence from professional football clubs. Journal of Intellectual Capital, 18(1), 63-80.

20. Lee, L. F., Hutton, A. P., \& Shu, S. (2015). The role of social media in the capital market: Evidence from consumer product recalls. Journal of Accounting Research, 53(2), 367-404.

21. Lishenga, L., \& Mbaka, A. (2015). The link between compliance with corporate governance disclosure code and performance for Kenyan firms. Net Journal of Business Management, 3(1), $13-26$.

22. Lodhia, S., \& Stone, G. (2017). Integrated reporting in an internet and social media communication environment: conceptual insights. Australian Accounting Review, 27(1), 17-33.

23. Meek, G. K., Roberts, C. B., \& Gray, S. J. (1995). Factors influencing voluntary annual report disclosures by US, UK and continental European multinational corporations. Journal of international business studies, 26(3), 555-572.

24. Miller, G. S., \& Skinner, D. J. (2015). The evolving disclosure landscape: How changes in technology, the media, and capital markets are affecting disclosure. Journal of Accounting Research, 53(2), 221-239.

25. Mohamed, E., \& Basuony, M. (2016). The use of social media for corporate disclosure by companies listed in the GCC. Information Technology Management Society ITMSOC-Transactions on Innovation \& Business Engineering, 1(1), 14-20.

26. Pástor, L., \& Pietro, V. (2003). Stock valuation and learning about profitability. The Journal of Finance, 58(5), 1749-1789.

27. Reilly, A.H. and Hynan, K.A., 2014. Corporate communication, sustainability, and social media: It's not easy (really) being green. Business horizons, 57(6), pp.747-758.

28. Susanti, N., \& Restiana, N. G. (2018). What's the Best Factor to Determining Firm Value? Jurnal Keuangan dan Perbankan, 22(2).

29. U.S. SEC. (2013). SEC Says Social Media OK for Company Announcements if Investors Are Alerted, Available at [https://www.sec.gov/news/press-release $/ 2013-2013-51 \mathrm{htm}]$

30. Zhou, M., Lei, L., Wang, J., Fan, W., \& Wang, A. G. (2014). Social media adoption and corporate disclosure. Journal of information systems, 29(2), 23-50. 